\title{
Screening and performance of $L-14$, a novel, highly efficient and low temperature-resistant cellulose-degrading strain
}

\author{
Guoxiang Zheng ${ }^{1,2,3 *}$, Zhaoxin $\mathrm{Lu}^{1,2}$, Jian $\mathrm{Li}^{1,3}$, Shuang $\mathrm{Ai}^{1,3}$, Yong Sun ${ }^{1,3}$ \\ (1. College of Engineering, Northeast Agricultural University, Harbin 150030, China; \\ 2. Key Laboratory of Pig-breeding Facilities Engineering, Ministry of Agriculture and Rural Affairs, Harbin 150030, China; \\ 3. Heilongjiang Key Laboratory of Technology and Equipment for the Utilization of Agricultural Renewable Resources, \\ Harbin 150030, China)
}

\begin{abstract}
In view of the low bioconversion efficiency of agricultural biomass waste in low-temperature environments in winter, a low-temperature-resistant cellulose-degrading strain, L-14, was successfully screened by restrictive cultures from humus-rich soil in the Daqing Zhalong wetland region. According to morphological observations and 18S rDNA sequence analysis, the cellulose-degrading strain L-14 was identified as a Neurospora sp, belonging to fungus. Different parameters, such as temperature, initial $\mathrm{pH}$, carbon, nitrogen and lecithin, were optimized using a single-factor experiment and a response surface methodology (RSM). When the temperature was $16^{\circ} \mathrm{C}$, the optimal conditions for enzyme production were an initial $\mathrm{pH} 8.20$, $10.45 \mathrm{~g} / \mathrm{L}$ of bran, $5.28 \mathrm{~g} / \mathrm{L}$ of yeast powder, and $4.25 \mathrm{~g} / \mathrm{L}$ of lecithin. The carboxymethyl cellulase (CMCase) activity of strain L-14 was $63.598 \mathrm{IU} / \mathrm{mL}$. Strain L-14 had a high level of cellulose degradation activity, excellent resistance to low temperatures and environmental adaptability, indicating its good application prospects in substrates pretreatment of biogas engineering.

Keywords: low-temperature-resistant, Neurospora sp., 18S rDNA sequence, carboxymethyl cellulase, response surface methodology
\end{abstract}

DOI: $10.25165 /$ j.ijabe.20201301.5128

Citation: Zheng G X, Lu Z X, Li J, Ai S, Sun Y. Screening and performance of L-14, a novel, highly efficient and low temperature-resistant cellulose-degrading strain. Int J Agric \& Biol Eng, 2020; 13(1): 247-254.

\section{Introduction}

There is much agricultural and forestry matter rich in fiber resources in northern China each year, and disposal of incineration products, storage as landfill or stacking of limbs results in a waste of resources and severe environmental pollution ${ }^{[1,2]}$. The average temperature is relatively low in Northeast China, most of the mesophilic and thermophilic cellulose degradation strains currently studied have common problems in practical applications, such as low enzyme activity, low-temperature resistance, and poor genetic stability $^{[3,4]}$. Low-temperature cellulase-producing bacteria usually grow in areas with an average annual temperature $\leq 5^{\circ} \mathrm{C}$. Coping with the degradation of physiological, biochemical and other properties caused by low temperature, these organisms synthesize enzymes that perform high-quality catalysis at low temperatures, but their thermal stability is very low ${ }^{[5]}$. To date, research on cellulose-degrading bacteria has been most concentrated on deep-sea psychrophile and cold-adapted bacteria. Few studies have focused on psychrotrophic cellulose-degrading bacteria $^{[6,7]}$. However, there are few studies on the screening and isolation of low temperature-tolerant strains in soil and wetlands.

\section{Received date: 2019-05-06 Accepted date: 2019-11-20}

Biographies: Zhaoxin Lu, MS student, research interests: agricultural engineering, Email: 1844498807@qq.com; Jian Li, MS student, research interests: environmental microbes, Email: 2270292544@qq.com; Shuang Ai, MS student, research interests: environmental microbes, Email: 1171140341@ qq.com; Yong Sun, PhD, Professor, research interests: high value utilization of agricultural and pastoral waste resources, Email: sunyong@ neau.edu.cn.

*Corresponding author: Guoxiang Zheng, PhD, Professor, research interests: environmental microbes. College of Engineering, Northeast Agricultural University, No. 600, Changjiang Road, Xiangfang District, Harbin 150030, China. Tel: +86-15104601708, Email: zgx720331@126.com.
In the northeast of China, the low-temperature season lasts about six months. Therefore, studies based on cryophile cellulose-degrading bacteria in the soil of the Daqing wetland and forest area in Heilongiiang Province of China have provided us with crucial information to enrich and expand various resources and apply low-temperature cellulose-degrading bacteria.

The objective of this study was to isolate a novel psychrotrophic cellulose-degrading strain, named L-14, by restriction culture screening, and to determine in detail the morphological observations, the $18 \mathrm{~S}$ rDNA sequences and the CMC enzyme production conditions, respectively. The cellulose-degrading strain L-14 was identified as a Neurospora sp, which belongs to fungus. Results laid a theoretical foundation for the application of low-temperature cellulose-degrading bacteria.

\section{Materials and methods}

\subsection{Preparation of microorganism and media}

Potato Dexrose Agar (PDA) medium: $300 \mathrm{~g}$ of freshly peeled diced potatoes were taken, and then $1000 \mathrm{~mL}$ distilled water was added. The potatoes were boiled for $30 \mathrm{~min}$. The residue was filtered, and the leaching solution was cold to room temperature. Then, $25 \mathrm{~g}$ of glucose and $15 \mathrm{~g}$ of agar were added to $1000 \mathrm{~mL}$ of distilled water at normal $\mathrm{pH}$. Finally, the solution was sterilized at $121^{\circ} \mathrm{C}$ and $101 \mathrm{kPa}$ for $25 \mathrm{~min}$.

Enrichment medium: $5 \mathrm{~g}$ peptone, $5 \mathrm{~g}$ filter paper, $0.5 \mathrm{~g} \mathrm{NaCl}$, $2 \mathrm{~g}$ yeast powder, $2 \mathrm{~g} \mathrm{CaCO}_{3}$, and $1000 \mathrm{~mL}$ distilled water. The solution was sterilized at $121^{\circ} \mathrm{C}$ and $101 \mathrm{kPa}$ for $25 \mathrm{~min}$.

Screening medium: $15 \mathrm{~g}$ sodium carboxymethyl cellulose, $2 \mathrm{~g}$ $\mathrm{MgSO}_{4}, 2 \mathrm{~g} \mathrm{KH}_{2} \mathrm{PO}_{4}, 1 \mathrm{~g} \mathrm{NH}_{4} \mathrm{NO}_{3}, 0.3 \mathrm{~g} \mathrm{NaCl}, 1 \mathrm{~g}$ yeast powder, $15 \mathrm{~g}$ agar, natural $\mathrm{pH}$, and $1000 \mathrm{~mL}$ distilled water. The solution was sterilized at $121^{\circ} \mathrm{C}$ and $101 \mathrm{kPa}$ for $25 \mathrm{~min}$. 
Liquid enzyme production medium: $15 \mathrm{~g}$ sodium carboxymethyl cellulose, $2 \mathrm{~g} \mathrm{MgSO}_{4}, 2 \mathrm{~g} \mathrm{KH}_{2} \mathrm{PO}_{4}, 1 \mathrm{~g} \mathrm{NH}_{4} \mathrm{NO}_{3}$, $0.3 \mathrm{~g} \mathrm{NaCl}, 2.2 \mathrm{~g} \mathrm{MnSO}_{4}, 0.01 \mathrm{~g} \mathrm{FeSO}_{4} \cdot 7 \mathrm{H}_{2} \mathrm{O}, 1 \mathrm{~g}$ yeast powder, and $1000 \mathrm{~mL}$ distilled water. The solution was sterilized at $121^{\circ} \mathrm{C}$ and $101 \mathrm{kPa}$ for $25 \mathrm{~min}$.

Cellulose medium: $10 \mathrm{~g}$ microcrystalline cellulose, $2 \mathrm{~g} \mathrm{MgSO}_{4}$, $2 \mathrm{~g} \mathrm{KH}_{2} \mathrm{PO}_{4}, 1 \mathrm{~g} \mathrm{NH}_{4} \mathrm{NO}_{3}, 0.3 \mathrm{~g} \mathrm{NaCl}, 2.2 \mathrm{~g} \mathrm{MnSO}_{4}, 0.01 \mathrm{~g}$ $\mathrm{FeSO}_{4} \cdot 7 \mathrm{H}_{2} \mathrm{O}, 1 \mathrm{~g}$ yeast powder, and $1000 \mathrm{~mL}$ distilled water. The solution was sterilized for $25 \mathrm{~min}$ at $121^{\circ} \mathrm{C}$ and $101 \mathrm{kPa}$.

\subsection{Isolation and identification of cellulase-producing} microorganisms

\subsubsection{Isolation and screening of strains}

Cultured substrate containing leaching solution was coated and then cultured in an incubator $(17 \pm 1)^{\circ} \mathrm{C}$ for 7-10 d. Colonies with good growth and different shapes were selected and scored to a single colony. The plate was cultured in an incubator at $5^{\circ} \mathrm{C}$ for 5-15 d, and well-grown colonies were selected. These plates were stained with Congo red staining and rinsed with $\mathrm{NaCl}$ solution. The size of the cellulose degradation hydrolysis zones of colonies was measured, and strains with good degradation ability were selected ${ }^{[8]}$. Two loops of pure bacteria were inoculated into enzyme production medium and cultured at $17^{\circ} \mathrm{C}$ in a $120 \mathrm{r} / \mathrm{min}$ shake flask for $7 \mathrm{~d}$ to determine the CMCase activities. The cellulose culture solution was treated in the same manner as the enzyme-producing medium, and the strains degraded microcrystalline cellulose. Based on the results of the above two experiments, the strains with high cellulase activity and good pure cellulose degradation were selected as the strains to be further investigated.

\subsubsection{Identification of strains}

The low-temperature cellulose-degrading bacteria were inoculated in beef extract peptone medium by the plate scribing method, and the cold-adapted cellulose-degrading bacteria were cultured at a constant temperature for $48 \mathrm{~h}$. Then, the colony morphology was observed. Physiological and biochemical identification was performed by referring to the Fungal Identification Manual and the Flora Fungorum Sinicorum ${ }^{[9]}$. In addition, 18S rDNA sequence analysis method of molecular biology was used, and the universal fungal primers were synthesized by the Shanghai Shenggong Co., Ltd. The specific reaction system and conditions were previously reported ${ }^{[10]}$. The $18 \mathrm{~S}$ rRNA gene sequences were compared with other 18S rRNA gene sequences available in the GenBank database, and a phylogenetic tree was constructed using MEGA7.0 software ${ }^{[11]}$.

\subsection{Methods of enzyme assay}

Filter paper enzyme activity (FPA) determination method: take $1 \mathrm{~mL}$ of crude enzyme solution diluted 5 times into a $25 \mathrm{~mL}$ stoppered test tube, add $2.5 \mathrm{~mL}$ of citric acid-sodium citrate buffer ( $\mathrm{pH} 4.8$ ), and use $50 \mathrm{mg}$ of filter paper as the substrate to be hydrolyzed. After $30 \mathrm{~min}$ of incubation in a water bath at $30^{\circ} \mathrm{C}$, the reaction was terminated by adding 3,5-dinitrosalicylic acid (DNS) to $3 \mathrm{~mL}$ of DNS coloring solution. After boiling for $10 \mathrm{~min}$ in a boiling water bath, the test tube was cooled to room temperature by cold water. The absorbance was measured at $540 \mathrm{~nm}$ by an ultraviolet spectrophotometer, and the reducing sugar content calculated based on a glucose standard curve was used to calculate the FPA (Table 1). The amount of enzyme required to produce $1 \mu \mathrm{g}$ of glucose (hydrolyzed product) per min is defined as one unit of enzyme activity, an IU.

CMCase activity assay: Cellulase activity was determined using international standard methods recommended by the International
Association of Theoretical and Applied Chemistry (IUPAC) ${ }^{[12]}$.

Enzyme activity calculation method:

$$
X=1000 \times A \times n / 180 / T
$$

where, $X$ is the units of enzyme activity, IU/Ml; $A$ is the glucose content $(\mathrm{mg} / \mathrm{mL})$ calculated by experimental determination of OD values and a standard curve; $n$ is the dilution factor; and $T$ is the reaction time, $\min$

Table 1 Standard factory glucose solution preparation

\begin{tabular}{lcccccc}
\hline \multicolumn{1}{c}{ Tube number } & 1 & 2 & 3 & 4 & 5 & 6 \\
\hline Glucose standard solution/mL & 0 & 0.2 & 0.4 & 0.6 & 0.8 & 1 \\
Distilled water/mL & 1 & 0.8 & 0.6 & 0.4 & 0.2 & 0 \\
DNS reagent/mL & 3 & 3 & 3 & 3 & 3 & 3 \\
Glucose concentration $/ \mathrm{mg} \cdot \mathrm{mL}^{-1}$ & 0 & 0.2 & 0.4 & 0.6 & 0.8 & 1.0 \\
\hline
\end{tabular}

Note: $y=7.2497 x-0.2765, R^{2}=0.9991$.

\subsection{Optimization of conditions for enzyme activity}

\subsubsection{Single-factor experiment optimization}

$\mathrm{pH}$ values of 3.0, 4.0, 5.0, 6.0, 7.0, 8.0 and 9.0 were used in the experiment groups. $\mathrm{pH}$ was used as a single variable in the experiment groups. Bran, corn flour, cellulose, filter paper and carboxymethyl cellulose-Na were used as the sole carbon source in the experimental groups. Ammonium sulfate, peptone, yeast powder, soy flour and urea were used as nitrogen sources in the experimental groups. All experiments were performed in triplicate, and after $9 \mathrm{~d}$ of culture at $(17 \pm 1)^{\circ} \mathrm{C}$, the cellulase activity was measured.

\subsubsection{Interactions among carbon}

Based on the results of single-factor experiments, a Plackett-Burman (PB) approach was used to design the experiments, analyze the experimental data and investigate the multifactor interaction of carbon source, nitrogen source, initial $\mathrm{pH}$, lecithin addition, culture temperature and culture time. When the number of factors in the test design is less than 19, an appropriate number of empty items are set in the test design, and each factor has two levels, high and low, which are respectively denoted " +1 " and " -1 ".

\subsubsection{Central Composite Design (CCD) test design}

The independent variables were the amounts of bran, yeast powder, and lecithin added and $\mathrm{pH}$, which were mainly used by the PB test as independent variables. The CCD method was used to optimize the enzyme production conditions, and CMCase activity was the only response variable and was used to verify whether the model was reliable. The experimental design factors are shown in Table 2. Experimental data from the CCD test were analyzed and fitted according to the second-order polynomial in Equation (1), which included direct effects and interaction effects for each variable:

$$
Y=a_{0}+\sum_{i=1}^{k} a_{i} X_{i}+\sum_{i=1}^{j-1} \sum_{j=1}^{k} a_{i j} X_{i} X_{j}+\sum_{i=1}^{k} a_{i j} X_{i}^{2}
$$

where, $Y$ is the enzyme activity; $a_{0}$ is the offset; $a_{i}$ is the linear offset; $a_{i j}$ is the second-order offset; $X_{i}$ is the value of each factor ${ }^{[13]}$

Table 2 CCD factor and level table for strain L-14

\begin{tabular}{ccccccc}
\hline \multirow{2}{*}{ Number } & Factor & \multicolumn{5}{c}{ Level } \\
\cline { 3 - 7 } & & -1.414 & -1 & 0 & 1 & 1.414 \\
\hline$X_{1}$ & Wheat bran & 6.3 & 7.5 & 10 & 12.5 & 13.8 \\
$X_{2}$ & Yeast Powder & 2.5 & 3.0 & 4 & 5.1 & 5.5 \\
$X_{3}$ & pH & 6.5 & 7.1 & 8 & 9.1 & 9.5 \\
$X_{4}$ & Lecithin & 2.5 & 3.0 & 4 & 5.0 & 5.5
\end{tabular}




\section{Results and analysis}

\subsection{Separation and screening of low-temperature-resistant} cellulose-degrading bacteria

The temperature was controlled at $(17 \pm 1)^{\circ} \mathrm{C}$. After 7-9 separations and purifications, Congo red staining was compared with the size of hydrolysis zones, the degradation of microcrystalline cellulose and the enzyme activity of liquid culture. A total of 10 low-temperature-resistant strains were screened. The strains with high enzyme activity are shown in Table 3. The CMCase activity of L-8, L-11 and L-14 were highest. A strain with the most CMCase activity ( $35.457 \mathrm{IU} / \mathrm{mL}$ ), designated L-14, was selected for characterization and further analysis. The degradation of microcrystalline cellulose was obvious, and the diameter of the hydrolysis zone was $8.6 \mathrm{~cm}$. Considering the three screening results, the selected strain L-14 was identified as the subject for further research.

Table 3 Strain screening results

\begin{tabular}{ccccc}
\hline Strain & $\begin{array}{c}\text { Transparent circle } \\
\text { diameter/cm }\end{array}$ & $\begin{array}{c}\text { Colony } \\
\text { diameter } \\
\text { /cm }\end{array}$ & $\begin{array}{c}\text { Degradation of } \\
\text { microcrystalline } \\
\text { cellulose }\end{array}$ & $\begin{array}{c}\text { CMCase } \\
\text { /IU. } \mathrm{mL}^{-1}\end{array}$ \\
\hline L-1 & 2.75 & 1.4 & + & 6.253 \\
L-2 & 6.2 & 2.5 & +++ & 23.102 \\
L-3 & 4.05 & 2.3 & ++ & 11.291 \\
L-4 & 5.4 & 2.0 & +++ & 18.102 \\
L-5 & 3 & 1 & + & 3.621 \\
L-6 & 6.7 & 6.55 & +++ & 23.704 \\
L-7 & 5.58 & 3.15 & ++++ & 26.067 \\
L-8 & 8.6 & 8.4 & ++++ & 33.825 \\
L-9 & 4.45 & 2.6 & ++ & 11.898 \\
L-10 & 4.75 & 2.9 & ++ & 12.765 \\
L-11 & 7.68 & 2.45 & ++++ & 39.266 \\
L-12 & 3.75 & 2.5 & ++ & 9.033 \\
L-13 & 3.3 & 1.85 & + & 9.245 \\
L-14 & 8.6 & 8.0 & ++++ & 35.457 \\
\hline Note: “+ & & & +19
\end{tabular}

Note: "+" indicates degradation of microcrystalline cellulose, "+" indicates the growth of the strain and that microcrystalline cellulose showed signs of degradation; "++" indicates weak degradation; "+++" indicates moderate degradation; and "++++" means that a good level of degradation occurs.

\subsection{Morphology of low-temperature-resistant cellulose-} degrading bacteria $\mathrm{L}-14$

The hydrolysis circle in the L-14 Congo red staining medium was large (Figure 1a), and there were loose hyphae that were pale pink, separated and branched on the screening medium. The colonies were net-like with no obvious edges, the hyphae were unstable, and the spores were highly diffusive, as shown in Figure 1b. As shown by the microscope in Figure 1c, the conidia were connected in a chain shape and grew directly from the hyphae. The spores were easily separated from each other after maturity, and the individual spores were dispersed in a free state on the medium surface. The spores were oval and had a smooth surface. According to colony morphology, the colony was preliminarily identified as a Neurospora sp. strain.

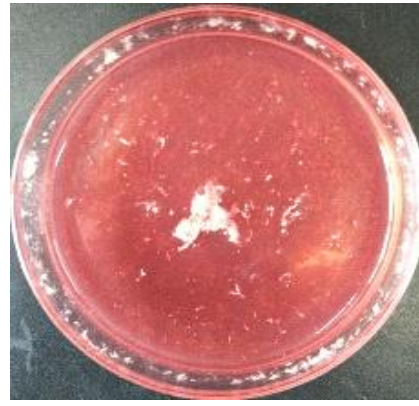

a. The picture shows the characteristics of the strain's Congo red-stained hydrolysis circle

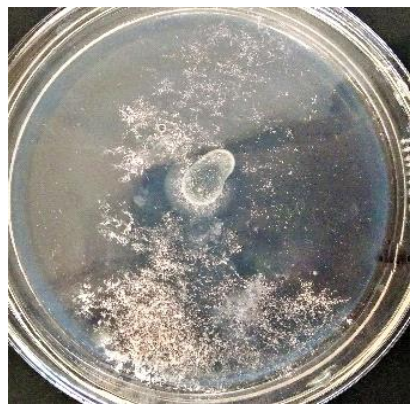

b. The growth morphology of the strain was connected to the screening medium

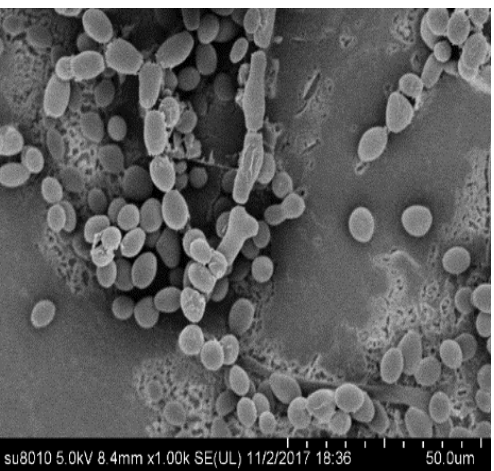

c. The picture shows the hyphae and spores observed under scanning electron microscopy

Figure 1 Morphological characteristics of strain L-14

3.3 Phylogenetic analysis based on 18S rDNA gene sequence

Molecular biological identification of L-14 strain: The strain's $18 \mathrm{~S}$ rDNA was amplified, and a $\mathrm{T}$ vector was ligated and sequenced to obtain a $1050 \mathrm{bp}$ sequence. The $18 \mathrm{~S}$ rDNA gene sequences were compared with $18 \mathrm{~S}$ rDNA gene sequences available in GenBank, and a phylogenetic tree was constructed by applying the neighbor-joining method using the MAGA 7.0 program. The L-14 strain was assigned to Neurospora sp. according to $98 \%$ similarity in their 18S rDNA gene sequences. The phylogenetic tree was constructed based on the 18S rDNA sequences (Figure 2).

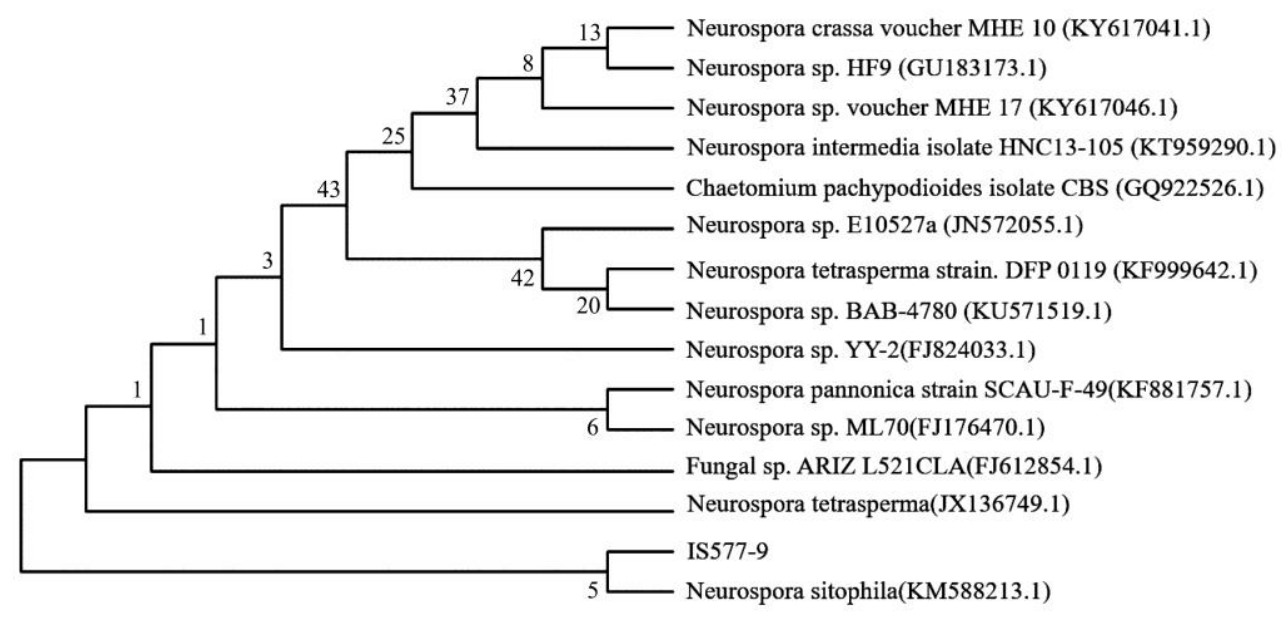

Figure 2 Phylogenetic tree with strain L-14 


\subsection{Enzymatic properties of strain L-14}

\subsubsection{Optimum temperature and thermal stability}

The effect of temperature on the activities of cellulases and filter paper enzymes produced by strain L-14 is shown in Figure 3. Both CMCs and filter paper enzymes produced by strain L-14 have their highest enzyme activity at $40^{\circ} \mathrm{C}$. When the temperature was between $20^{\circ} \mathrm{C}-50^{\circ} \mathrm{C}$, the relative enzyme activity of cellulases and filter paper enzymes was maintained above $70 \%$; the relative enzyme activity was also maintained above $50 \%$ at $5{ }^{\circ} \mathrm{C}$. CMCase activity increased with increasing temperature between 5 and $40^{\circ} \mathrm{C}$ until an optimum was reached. In contrast, a further increase in temperature above $40^{\circ} \mathrm{C}$ caused CMCase activity to gradually decrease. The cellulase and filter paper enzymes produced by strain L-14 showed high enzyme activity between $25^{\circ} \mathrm{C}-50^{\circ} \mathrm{C}$. Both enzymes can adapt to low and high temperatures.

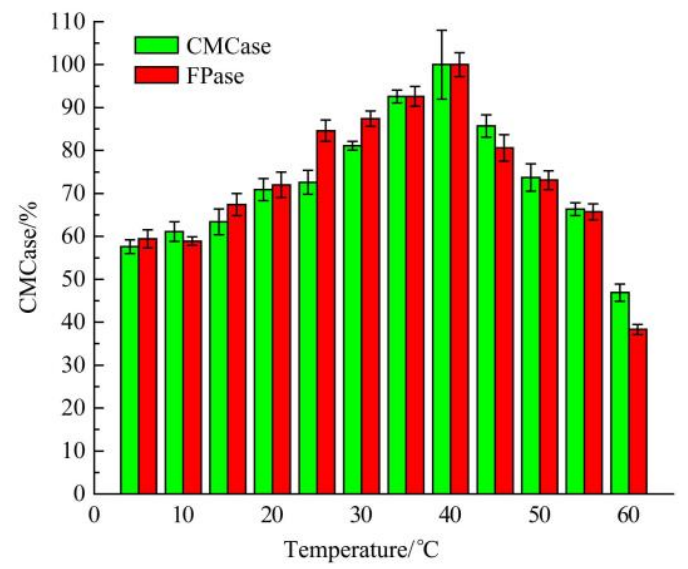

Figure 3 Effect of temperature on the enzyme activity of strain L-14

The relative stability of the cellulase activity of strain L-14 at different temperatures for $0.5-2 \mathrm{~h}$ is shown in Figure 4 . After $2 \mathrm{~h}$ of storage at $5^{\circ} \mathrm{C}$, more than $90 \%$ of the CMCase activity was retained, and the cellulase stability was the highest in this sample. The cellulase relative activity was maintained above $80 \%$ at the temperature of $5^{\circ} \mathrm{C}-20^{\circ} \mathrm{C}$. The CMCase activity decreased as the temperature increased beyond above $30^{\circ} \mathrm{C}$. The relative enzyme activity was $44 \%$ after $2 \mathrm{~h}$ of incubation at $30^{\circ} \mathrm{C}$ and almost completely lost after $2 \mathrm{~h}$ at $50^{\circ} \mathrm{C}$. This result was consistent with the low-temperature enzyme properties.

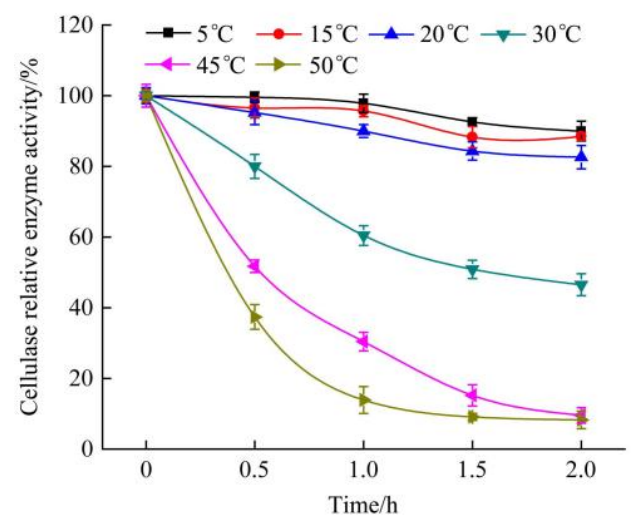

Figure 4 Effect of storage temperature on the stability of L-14 cellulase relative enzyme activity

\subsubsection{Effect of $\mathrm{pH}$ on enzyme activity}

Figure 5 presents the CMCase activity of the L-14 fermentation cultures at different initial $\mathrm{pH}$ values. CMCase from strain L-14 had the highest activity at $\mathrm{pH}$ 5.0. The enzyme was approximately
$70 \%$ of its maximum activity at $\mathrm{pH} 4.0-9.0$. In addition, more than $80 \%$ of the relative activity was maintained at $\mathrm{pH} 5.0-8.0$. The pH-based trends in CMCase activity and FPA were basically the same for strain L-14. These two types of enzymes of strain L-14 prefer to act in a neutral alkaline environment.

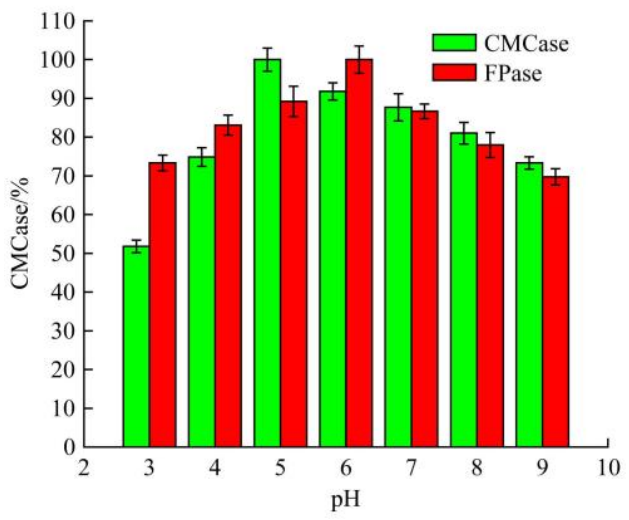

Figure 5 Effect of $\mathrm{pH}$ on the stability of L-14 enzyme activity 3.4.3 Effect of metal ions on cellulase enzyme activity

The effect of adding metal ions to the crude enzyme solution of strain L-14 is shown in Figure 6. $\mathrm{Ca}^{2+}, \mathrm{Na}^{+}, \mathrm{Co}^{2+}$ and a small amount of $\mathrm{Fe}^{2+}$ promoted the cellulase activity of strain L-14. The enzyme activity was obvious when the concentration of $\mathrm{Co}^{2+}$ was low. When $0.6 \mathrm{mg} / \mathrm{L} \mathrm{Co}^{2+}$ was added, the relative activity of cellulase was the highest, and the highest value was $135 \%$. When the $\mathrm{Co}^{2+}$ concentration was $0.3 \mathrm{mg} / \mathrm{L}$, the relative activity of cellulase was $117 \%$. The CMCase activity decreased rapidly as the amount of $\mathrm{Co}^{2+}$ increased beyond $0.6 \mathrm{mg} / \mathrm{L}$, indicating that the activity of the enzyme was obvious at low concentrations. The promotion by $\mathrm{Na}^{+}$and $\mathrm{Ca}^{2+}$ ions was relatively stable. When the concentration of $\mathrm{Na}^{+}$was $0.3 \mathrm{mg} / \mathrm{L}$, the relative cellulase activity was $127 \%$; when the $\mathrm{Ca}^{2+}$ concentration was $0.6 \mathrm{mg} / \mathrm{L}$, the relative cellulase activity was $121 \%$. The relative enzyme activity was $97 \%$ when $0.3 \mathrm{mg} / \mathrm{L} \mathrm{Fe}^{2+}$ was added. When the $\mathrm{Fe}^{2+}$ concentration was increased to $0.6 \mathrm{mg} / \mathrm{L}$, the relative enzyme activity increased to $117 \%$, followed by a downward trend with further increasing concentration. $\mathrm{Mg}^{2+}$ and $\mathrm{Mn}^{2+}$ ions had a negative effect on the enzyme activity that was enhanced with further addition of $\mathrm{Mg}^{2+}$ and $\mathrm{Mn}^{2+}$. When the $\mathrm{Mg}^{2+}$ and $\mathrm{Mn}^{2+}$ concentration reached $1.2 \mathrm{mg} / \mathrm{L}$, the corresponding relative enzyme activities were $62 \%$ and $48 \%$, respectively. CMCase activity in the fermentation cultures with various metal ions was in order of $\mathrm{Co}^{2+}>\mathrm{Na}^{+}>\mathrm{Ca}^{2+}>\mathrm{Fe}^{2+}>\mathrm{Mg}^{2+}>$ $\mathrm{Mn}^{2+}$.

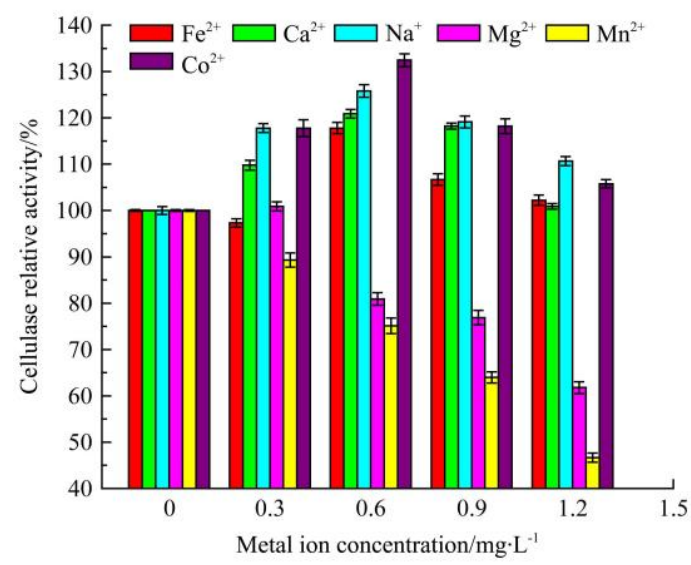

Figure 6 Effect of metal ions on strain L-14 CMCase

3.4.4 Optimization of enzyme production

The optimum operating temperature of the CMCase was 
assessed from $10^{\circ} \mathrm{C}$ to $20^{\circ} \mathrm{C}$ with an interval of $2^{\circ} \mathrm{C}$. The results are shown in Figure 7. The strain L-14 CMCase activity first increased and then showed a downward trend. The curve decreased slightly between $16^{\circ} \mathrm{C}-18^{\circ} \mathrm{C}$, and with increasing temperature, the activity of CMCase decreased significantly. The cultures grown at $16^{\circ} \mathrm{C}$ exhibited the greatest CMCase activity $(33.504 \mathrm{IU} / \mathrm{mL})$ and the best growth, indicating that strain L-14 produced the most cellulase when cultured at $16^{\circ} \mathrm{C}-18^{\circ} \mathrm{C}$. As the $\mathrm{pH}$ increased, the CMCase activity of strain L-14 gradually increased (Figure 8), and reached a maximum of $41.241 \mathrm{IU} / \mathrm{mL}$ at $\mathrm{pH}$ 8.0. When the $\mathrm{pH}$ value was between 8.0 and 9.0, the CMCase activity decreased gently, indicating that L-14 could grow in an alkaline environment and that the enzyme produced was adapted to a wide range of initial medium $\mathrm{pH}$ values. Therefore, the initial $\mathrm{pH}$ value suitable for the enzyme is between 7.0 and 9.0.

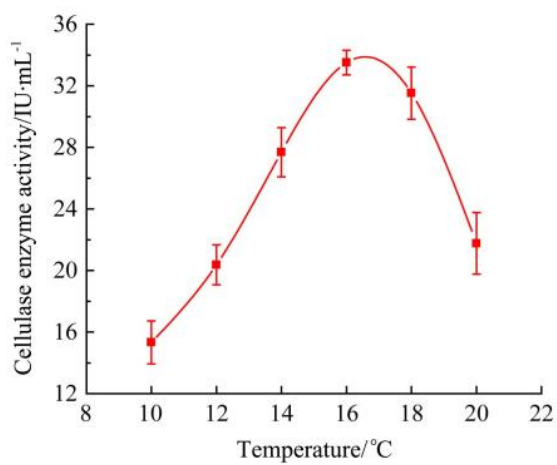

Figure 7 Effect of culture temperature on the cellulase activity of strain L-14

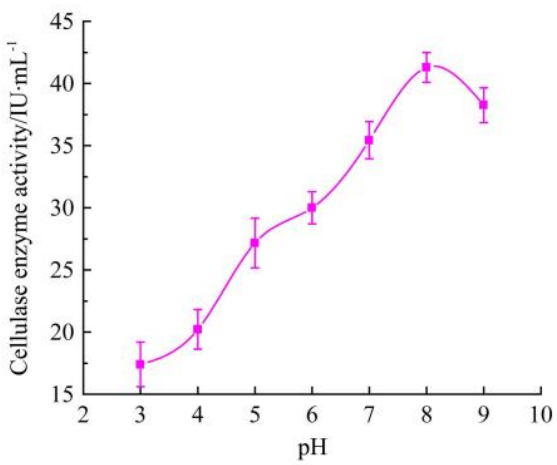

Figure 8 Effect of initial $\mathrm{pH}$ value on the cellulase enzyme activity of strain L-14

The effects of carbon sources on L-14 enzyme activity are shown in Table 4. The result showed that L-14 has high CMCase activity cultured in fermentation medium with sodium carboxymethyl cellulose and reached its highest CMCase activity when 7.5-12.5 g/L bran was added. The optimal concentration of bran in the medium was $10 \mathrm{~g} / \mathrm{L}$, where the CMCase activity reached $43.445 \mathrm{IU} / \mathrm{mL}$.

Table 4 Effect of carbon sources on cellulase produced by strain L-14

\begin{tabular}{cccccc}
\hline & \multicolumn{5}{c}{ Variety carbon sources } \\
\cline { 2 - 6 } Addition $/ \mathrm{g} \cdot \mathrm{L}^{-1}$ & Wheat bran & Corn meal & Cellulose & Filter paper & CMC-Na \\
\cline { 2 - 6 } & 20.372 & 10.066 & 10.916 & 13.873 & 26.371 \\
\cline { 2 - 6 } & 32.012 & 12.693 & 16.530 & 15.950 & 37.074 \\
7.5 & 43.445 & 16.131 & 21.041 & 14.515 & 29.741 \\
10 & 34.950 & 9.619 & 17.182 & 9.253 & 22.802 \\
12.5 & 17.564 & 4.226 & 14.1895 & 8.108 & 19.445 \\
15 & &
\end{tabular}

The effects of nitrogen sources on L-14 enzyme activity are shown in Table 5. The organic nitrogen is more beneficial to enzyme production by strain L-14 than the inorganic nitrogen sources ammonium sulfate and urea. When the organic nitrogen sources of peptone, yeast powder and soybean powder were present at 4-5 g/L, the CMCase activity of strain L-14 reached its corresponding maximum values of $16.602 \mathrm{IU} / \mathrm{mL}, 49.790 \mathrm{IU} / \mathrm{mL}$ and $37.885 \mathrm{IU} / \mathrm{mL}$, respectively, demonstrating that the enzyme-producing effect of strain L-14 was preferable when the yeast powder concentration was 3-6 $\mathrm{g} / \mathrm{L}$ or the soybean powder concentration was $4-6 \mathrm{~g} / \mathrm{L}$.

Table 5 Effect of nitrogen sources on cellulase produced by strain L-14

\begin{tabular}{cccccc}
\hline & \multicolumn{5}{c}{ Variety carbon sources } \\
\cline { 2 - 6 } $\begin{array}{c}\text { Addition } \\
\text { /g. } \mathrm{L}^{-1}\end{array}$ & Peptone & Yeast powder $\begin{array}{c}\text { Ammonium } \\
\text { sulfate }\end{array}$ & $\begin{array}{c}\text { Soybean } \\
\text { powder }\end{array}$ & Urea \\
\cline { 2 - 6 } & 5.694 & 8.324 & 18.467 & 17.010 & 7.241 \\
\hline 1 & 13.148 & 25.126 & 22.935 & 17.780 & 8.204 \\
2 & 15.784 & 34.484 & 14.773 & 15.025 & 6.167 \\
3 & 16.602 & 47.320 & 13.596 & 37.885 & 3.870 \\
4 & 12.086 & 49.791 & 10.122 & 32.368 & 3.056 \\
5 & 7.482 & 40.826 & 9.621 & 19.054 & 1.889 \\
6 & \multicolumn{5}{c}{$\mathrm{CMCase} / \mathrm{IU} \cdot \mathrm{mL}^{-1}$} \\
\hline
\end{tabular}

\subsection{Screening for significant factors}

3.5.1 Plackett-Burman design

A PB design was used to optimize key factors influencing enzyme-producing effect of strain L-14 with CMCase activity as the response value. Variance analysis of the $\mathrm{PB}$ test showed that the four factors most influential to strain L-14 CMCase activity were ranked as $X_{8}$ (initial $\left.\mathrm{pH}\right)>X_{2}$ (bran added) $=X_{4}$ (yeast powder added) $>X_{16}$ (lecithin added). As shown in Table 6 , the $\mathrm{p}$ values were all less than 0.01, indicating that these four factors had a significant impact on CMCase activity, and were used as the main factors for CCD optimization experiments.

Table 6 PB ANOVA results for strain L-14

\begin{tabular}{cccccc}
\hline Factors & $\begin{array}{c}\text { Sum of } \\
\text { square }\end{array}$ & $\begin{array}{c}\text { Degrees of } \\
\text { freedom }\end{array}$ & $\begin{array}{c}\text { Mean } \\
\text { square }\end{array}$ & $F$ value & $p$ value \\
\hline$X_{1}$ & 5.200 & 1 & 5.200 & 450.848 & 0.030 \\
$X_{2}$ & 278.693 & 1 & 278.693 & 24161.897 & 0.004 \\
$X_{3}$ & 32.378 & 1 & 32.378 & 2807.102 & 0.012 \\
$X_{4}$ & 345.150 & 1 & 345.150 & 29923.525 & 0.004 \\
$X_{5}$ & 3.105 & 1 & 3.105 & 269.164 & 0.039 \\
$X_{6}$ & 0.214 & 1 & 0.214 & 18.555 & 0.145 \\
$X_{7}$ & 8.763 & 1 & 8.763 & 759.764 & 0.023 \\
$X_{8}$ & 412.246 & 1 & 412.246 & 35740.520 & 0.003 \\
$X_{9}$ & 6.787 & 1 & 6.787 & 588.449 & 0.026 \\
$X_{10}$ & 11.625 & 1 & 11.625 & 1007.821 & 0.020 \\
$X_{11}$ & 0.388 & 1 & 0.388 & 33.654 & 0.109 \\
$X_{12}$ & 15.870 & 1 & 15.870 & 1375.880 & 0.017 \\
$X_{13}$ & 21.930 & 1 & 21.930 & 1901.254 & 0.015 \\
$X_{14}$ & 0.575 & 1 & 0.575 & 49.884 & 0.090 \\
$X_{15}$ & 7.729 & 1 & 7.729 & 670.048 & 0.025 \\
$X_{16}$ & 210.997 & 1 & 210.997 & 18292.858 & 0.005 \\
$X_{18}$ & 1.099 & 1 & 1.099 & 95.273 & 0.065 \\
$X_{19}$ & 4.676 & 1 & 4.676 & 405.356 & 0.032 \\
Model & 1367.425 & 18 & 75.968 & 6586.214 & 0.009 \\
Residue value & 0.012 & 1 & 0.012 & & \\
All items & 1367.437 & 19 & & & \\
\hline & 1 & & & \\
$X_{1}-X_{1}$ & & 1 & 1 & & \\
\hline
\end{tabular}

Note: $X_{1}-X_{19}$ in the table indicate different factors, $p<0.05$ indicates that the factor or model is significant, and $p<0.01$ indicates that the factor or model is extremely significant. 
3.5.2 Optimization of the response surface experiment

The response surface experimental design and its results are shown in Table 7. Design-Expert 8.0 software was used to carry out a response surface regression analysis of the experimental results to obtain optimal enzyme production conditions for $X_{2}$ (bran addition), $X_{4}$ (yeast powder addition), $X_{8}$ (initial $\mathrm{pH}$ ), and $X_{16}$ (lecithin addition). The multivariate quadratic equation was as follows:

$$
\begin{aligned}
Y= & 60.028+3.057 X_{1}+3.458 X_{2}+2.854 X_{3}+4.173 X_{4}+ \\
& 2.333 X_{1} X_{2}+1.333 X_{1} X_{3}-1.709 X_{1} X_{4}+1.126 X_{2} X_{3}+ \\
& 1.258 X_{2} X_{4}+1.618 X_{3} X_{4}-9.852 X_{1}^{2}-8.002 X_{2}^{2}- \\
& 9.322 X_{3}^{2}-9.012 X_{4}^{2}
\end{aligned}
$$

\begin{tabular}{|c|c|c|c|c|c|}
\hline Test number & $X_{1}$ & $X_{2}$ & $X_{3}$ & $X_{4}$ & $Y$ \\
\hline 1 & 0 & 1.414 & 0 & 0 & 46.310 \\
\hline 2 & -1 & -1 & -1 & -1 & 14.997 \\
\hline 3 & 1.414 & 0 & 0 & 0 & 41.926 \\
\hline 4 & -1.414 & 0 & 0 & 0 & 36.054 \\
\hline 5 & -1 & 1 & 1 & 1 & 34.369 \\
\hline 6 & 0 & 0 & 0 & 0 & 57.590 \\
\hline 7 & -1 & 1 & 1 & -1 & 15.597 \\
\hline 8 & 1 & -1 & 1 & 1 & 26.591 \\
\hline 9 & 0 & 0 & 0 & 0 & 61.594 \\
\hline 10 & 0 & 0 & 0 & -1.414 & 34.795 \\
\hline 11 & 0 & 0 & 0 & 0 & 63.215 \\
\hline 12 & 1 & 1 & -1 & 1 & 28.671 \\
\hline 13 & -1 & -1 & 1 & -1 & 14.911 \\
\hline 14 & 1 & 1 & 1 & -1 & 34.449 \\
\hline 15 & 0 & 0 & 1.414 & 0 & 40.250 \\
\hline 16 & 1 & -1 & -1 & 1 & 18.877 \\
\hline 17 & 1 & 1 & 1 & 1 & 45.637 \\
\hline 18 & 0 & 0 & -1.414 & 0 & 39.850 \\
\hline 19 & 0 & -1.414 & 0 & 0 & 39.071 \\
\hline 20 & 0 & 0 & 0 & 1.414 & 46.545 \\
\hline 21 & 0 & 0 & 0 & 0 & 60.384 \\
\hline 22 & -1 & 1 & -1 & 1 & 24.483 \\
\hline 23 & -1 & 1 & -1 & -1 & 14.431 \\
\hline 24 & 0 & 0 & 0 & 0 & 59.625 \\
\hline 25 & 0 & 0 & 0 & 0 & 60.304 \\
\hline 26 & 0 & 0 & 0 & 0 & 62.005 \\
\hline 27 & 0 & 0 & 0 & 0 & 59.326 \\
\hline 28 & 1 & 1 & -1 & -1 & 25.203 \\
\hline 29 & 0 & 0 & 0 & 0 & 62.590 \\
\hline 30 & 1 & -1 & 1 & -1 & 22.683 \\
\hline 31 & 1 & -1 & -1 & -1 & 17.689 \\
\hline 32 & -1 & -1 & 1 & 1 & 27.403 \\
\hline 33 & 0 & 0 & 0 & 0 & 61.974 \\
\hline 34 & 0 & 0 & 0 & 0 & 58.473 \\
\hline 35 & 0 & 0 & 0 & 0 & 58.576 \\
\hline 36 & -1 & -1 & -1 & 1 & 20.769 \\
\hline
\end{tabular}

Table 7 CCD and results for strain L-14

Note: The numerals 1-30 represent 30 different experimental conditions, and $Y$ represents carboxymethyl cellulose activity $(\mathrm{IU} / \mathrm{mL})$.

The regression analysis of the equation is shown in Table 8 . The fit of the model used for strain L-14 resulted in $p<0.01$, which suggested that the regressed fit of the equation was extremely significant; thus, there is a significant regression relationship between CMCase activity and these independent variables. The $R^{2}$, predictive $R^{2}$ and regression equation fitting values were $98.93 \%$, $96.07 \%$ and 0.0961 , respectively, which suggested that this model was of high reliability and well reflected the actual situation. A 3-D stereogram was used to display the responses to the interaction between the four major influencing factors of Neurospora sp. L-14 and the range of optimal values is 9.6-11.4 $\mathrm{g} / \mathrm{L}$ of bran, 4.9-5.6 g/L of yeast powder, $\mathrm{pH} 7.9-8.8$ and 3.9-4.5 $\mathrm{g} / \mathrm{L}$ of lecithin, respectively ${ }^{[14,15]}$. According to the $\mathrm{F}$ value and the degree of the slope of the response surface (Figure 9), the influence of each factor on the CMCase activity was in the order $X_{1} X_{2}$ (the amount of bran added and the amount of yeast powder added) $>X_{1} X_{4}$ (the amount of bran added and the amount of lecithin added) $>X_{3} X_{4}(\mathrm{pH}$ and lecithin addition amount) $>X_{1} X_{3}$ (bran addition amount and $\mathrm{pH}$ ) > $X_{2} X_{4}$ (amount of soybean powder added and amount of lecithin added).

Table 8 Analysis of variance (ANOVA) of strain L-14

\begin{tabular}{cccccc}
\hline Source & $\begin{array}{c}\text { Degrees of } \\
\text { freedom }\end{array}$ & $\begin{array}{c}\text { Sum of } \\
\text { square }\end{array}$ & $\begin{array}{c}\text { Mean } \\
\text { square }\end{array}$ & $F$ value & $\begin{array}{c}p \text { value } \\
(\text { Prob }>F)\end{array}$ \\
\hline$X_{1}$ & 186.924 & 1 & 186.924 & 35.633 & $<0.0001$ \\
$X_{2}$ & 239.138 & 1 & 239.138 & 45.586 & $<0.0001$ \\
$X_{3}$ & 162.942 & 1 & 162.942 & 31.061 & $<0.0001$ \\
$X_{4}$ & 348.251 & 1 & 348.251 & 66.386 & $<0.0001$ \\
$X_{1} X_{2}$ & 87.049 & 1 & 87.049 & 16.594 & 0.0005 \\
$X_{1} X_{3}$ & 28.409 & 1 & 28.409 & 5.415 & 0.0300 \\
$X_{1} X_{4}$ & 46.704 & 1 & 46.704 & 8.903 & 0.0071 \\
$X_{2} X_{3}$ & 20.268 & 1 & 20.268 & 3.864 & 0.0627 \\
$X_{2} X_{4}$ & 25.301 & 1 & 25.301 & 4.823 & 0.0395 \\
$X_{3} X_{4}$ & 41.861 & 1 & 41.861 & 7.980 & 0.0101 \\
$X_{1}{ }^{2}$ & 943.962 & 1 & 943.962 & 179.943 & $<0.0001$ \\
$X_{2}{ }^{2}$ & 622.733 & 1 & 622.733 & 118.709 & $<0.0001$ \\
$X_{3}{ }^{2}$ & 845.130 & 1 & 845.130 & 161.104 & $<0.0001$ \\
$X_{4}{ }^{2}$ & 789.856 & 1 & 789.856 & 150.567 & $<0.0001$ \\
Model & 10222.744 & 14 & 730.196 & 139.194 & $<0.0001$ \\
Salvage value & 110.164 & 21 & 5.246 & & \\
Missing item & 74.325 & 10 & 7.433 & 2.281 & 0.0961 \\
Pure error & 35.838 & 11 & 3.258 & & \\
All items & 10332.908 & 35 & & & \\
\hline
\end{tabular}

Note: $R^{2}=98.93 \%$, Pred $R^{2}=96.07 \%$.

3.5.3 Determination of optimal conditions and verification of recovery models

When the culture temperature is $16^{\circ} \mathrm{C}$, the optimum conditions for the production of Neurospora sp. L-14 were as follows: $4.25 \mathrm{~g} / \mathrm{L}$ lecithin, 10.45 bran $\mathrm{g} / \mathrm{L}, 5.28 \mathrm{~g} / \mathrm{L}$ yeast powder and initial $\mathrm{pH}$ 8.20. Under these conditions, the theoretical value of CMCase activity was $61.5978 \mathrm{IU} / \mathrm{mL}$. The actual experimental conditions were $4 \mathrm{~g} / \mathrm{L}$ lecithin, $10 \mathrm{~g} / \mathrm{L}$ bran, $5 \mathrm{~g} / \mathrm{L}$ yeast powder, and initial $\mathrm{pH}$ 8.0. Under these conditions, the L-14 CMCase activity of Neurospora sp. 14 was obtained: $60.590 \mathrm{IU} / \mathrm{mL}$, which was very close to the theoretical value.

At present, many of the cellulose-degrading bacteria screened by conventional methods had optimum CMCase activity at $45^{\circ} \mathrm{C}$ $65^{\circ} \mathrm{C}$, shown in Table 9, which have better cellulose degradation capacity. These bacterial include Penicillium oxalicum QSH3-3, Streptomyces L1 and Mutant strain CNY01. Compared with the above bacterial, strain L-14 screened by our laboratory has a higher tolerance to low temperature and better CMCase production. In our study, optimal conditions for enzyme production and low-temperature-resistant characteristics of strain L-14 were in detail investigated, and the CMCase activity reaches $35.457 \mathrm{IU} / \mathrm{mL}$ 
at $15^{\circ} \mathrm{C}, 80 \%$ of the relative activity was maintained at $\mathrm{pH}$ values ranging from 6.0 to 8.0 , demonstrating that strain L-14 exhibits
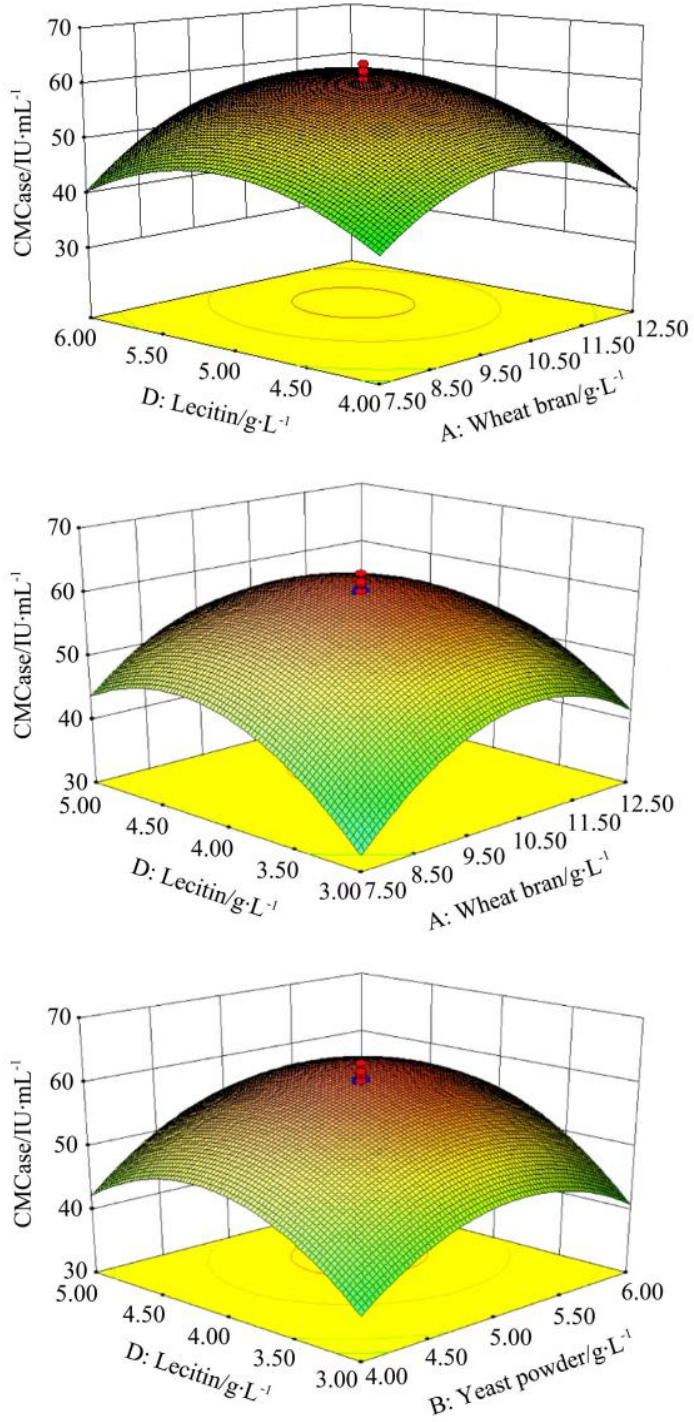

high thermal stability and substantial $\mathrm{pH}$ stability and retains its activity over a wide $\mathrm{pH}$ range.
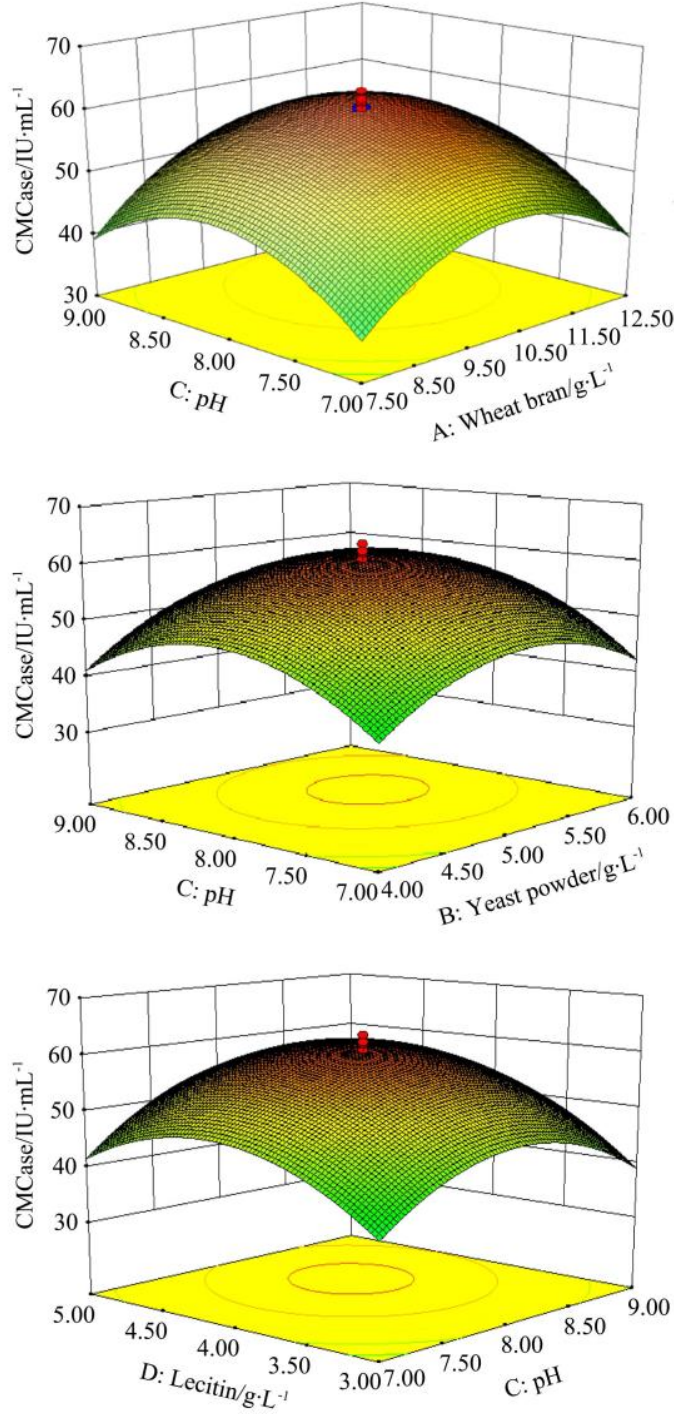

Figure 9 Response diagram for the interaction of two factors on the enzyme production of Neurospora sp. L-14

Table 9 Comparison of cellulose degradation characteristics

\begin{tabular}{|c|c|c|c|}
\hline $\begin{array}{c}\text { Low } \\
\text { temperature } \\
\text { tolerance strain }\end{array}$ & $\begin{array}{c}\text { Optimum fermentation } \\
\text { conditions }\end{array}$ & CMCase & Reference \\
\hline $\begin{array}{c}\text { Neurospora sp. } \\
\text { L-14 }\end{array}$ & $\begin{array}{l}\text { wheat bran } 10.45 \mathrm{~g} / \mathrm{L} \\
\text { yeast powder } 5.28 \mathrm{~g} / \mathrm{L} \\
\text { pH } 8.20 \\
\text { lecithin } 4.25 \mathrm{~g} / \mathrm{L}\end{array}$ & $61.598 \mathrm{IU} / \mathrm{mL}$ & - \\
\hline $\begin{array}{l}\text { Penicillium } \\
\text { oxalicum } \\
\text { QSH3-3 }\end{array}$ & $\begin{array}{l}\text { corn stalk powder } 5 \mathrm{~g} / \mathrm{L} \\
\text { Ammonium sulfate } 2 \mathrm{~g} / \mathrm{L} \\
\text { Initial } \mathrm{pH} 7.0 \\
\text { culture temperature } 30^{\circ} \mathrm{C}\end{array}$ & $33.000 \mathrm{IU} / \mathrm{mL}$ & Liu et al. ${ }^{[16]}$ \\
\hline $\begin{array}{c}\text { Streptomyces } \\
\text { L1 }\end{array}$ & - & $46.59 \mathrm{IU} / \mathrm{mL}$ & Zhang et al. ${ }^{[17]}$ \\
\hline $\begin{array}{l}\text { Mutant strain } \\
\text { CNY01 }\end{array}$ & $\begin{array}{l}\text { straw powder } 12 \mathrm{~g} / \mathrm{L} \\
\text { wheat bran } 7 \mathrm{~g} / \mathrm{L} \\
\text { ammonium sulfate } 5 \mathrm{~g} / \mathrm{L} \\
\text { potassium dihydrogen } \\
\text { phosphate } 5.5 \mathrm{~g} / \mathrm{L}\end{array}$ & $108.55 \mathrm{IU} / \mathrm{mL}$ & Chen et al. ${ }^{[18]}$ \\
\hline
\end{tabular}

\section{Conclusions}

Low temperature is always one of the key restrictive factors confining lignocelluloses bioconversion in wastes disposal yield. So the research on low temperature-resistant bacteria has been greatly concerned in recent years. In this study, by restricting culture method, a strain L-14 was obtained from different soil samples of the Northeast cold region in China, and identified as a fungus, which shows a $98 \%$ similarity of $18 \mathrm{~S}$ rDNA gene sequences with that of Neurospora sp. In this study, four significant factors including lecitin, $\mathrm{pH}$, bran and yeast were screened by plackett-burman design on the basis of single factor experiment, and then the optimal fermentation conditions were determined by box-behnken central combination design experiment. The results showed that the optimal enzyme production conditions of Neurospora 1-14 were as follows: $10.45 \mathrm{~g} / \mathrm{L}$ of bran, $5.28 \mathrm{~g} / \mathrm{L}$ of yeast, $\mathrm{pH}$ of 8.20 , and $4.25 \mathrm{~g} / \mathrm{L}$ of lecithin. Under this optimization condition, CMCase reached $61.598 \mathrm{IU} / \mathrm{mL}, 1.74$ times the previous optimization. The research provides important strain resources for exploring the lignocellulose degradation mechanism of low temperature-resistant microbials and solving the in-situ return and comprehensive utilization of crop straw in the cold region of Northeast in China.

\section{Acknowledgements}

This work was supported by National Key R\&D Program of China (2019YFD1100603), National key research and development plan project (2017YFD0700705) and Postdoctoral Launch Fund of Heilongjiang Provance (LBH-Q13023). 


\section{[References]}

[1] Connell L, Redman R, Craig S, Scorzetti G, Iszard M, Rodriguez R. Diversity of soil yeasts isolated from South Victoria Land, Antarctica. Microbial Ecology, 2008; 56(3): 448-459.

[2] Kang P, Morrow G, Zhang X L, Wang T P, Tan Z F, Agarwal J. Systematic comparison of hydrogen production from fossil fuels and biomass resources. Int J Agric \& Biol Eng, 2017; 10(6): 192-200.

[3] Wang Q, Li S N, Li H Y, Lei B S, Chen Y, Zhang L J, et al. Screening and identification on capable of degrading cellulose of produce spore cellulose decomposing bacteria xn-13. Chinese Agricultural Science Bulletin, 2009; 25(11): 180-185. (in Chinese)

[4] Zhao G, Ma F, Wei L, Cai H, Wang Z. Research and prospects of low temperature biogas digestion technology in North. Journal of Harbin Institute of Technology, 2011; 43(6): 29-33. (in Chinese)

[5] Saloheimo M. Swollenin, a Trichoderma reesei protein with sequence similarity to the plant expansins, exhibits disruption activity on cellulosic materials. Eur. J. Biochem., 2002; 269(17): 4202-4211.

[6] Hamelinck C N, Hooijdonk G., Faaij A P C. Ethanol from lignocellulosic biomass: techno-economic performance in short-, middle- and long-term. Biomass Bioenerg, 2005; 28: 384-410.

[7] Zhang X F, Yao T D, Tian L D, Xu S J, An L Z. Phylogenetic and physiological diversity of bacteria isolated from Puruogangri ice core. Microbial Ecology, 2008; 55(3): 476-488.

[8] Feller U. Moderately high temperatures inhibit ribulose-1,5-bisphosphate carboxylase/oxygenase (rubisco) activase-mediated activation of rubisco. Plant Physiology, 1998; 116(2): 539-546.

[9] Jarvinen K T, Melin E S, Puhakka J A. High-rate bioremediation of chlorophenol-contaminated groundwater at low temperatures. Environmental Science \& Technology, 1994; 28(13): 2387-2392.
[10] Li X M, Jia B X. Isolation and identification of an equol-producing bacterial strain from vegetarian intestinal tract. Food Science, 2014; 35(3) 153-156. (in Chinese)

[11] Li C Y, Xu C H, Pan J B. Isolation of a Chlorimuron-Ethyl Degradation Bacterium and Its Bioremediation in Contamination Soil. International Conference on Bioinformatics \& Biomedical Engineering. IEEE. 2011. doi: 10.1109/icbbe.2011.5780302

[12] Kumar S, Nei M, Dudley J, Tamura K. Mega: a biologist-centric software for evolutionary analysis of DNA and protein sequences. Briefings in Bioinformatics, 2008; 9(4): 299-306.

[13] Zhao Z Y, Huang Q F, Wang Q. Research progress on the degradation of deca-bdes. Research of Environmental Sciences, 2014; 27(5): 554-559.

[14] Teng G S, Liu Y, Wu L D, Fan C Y, Wang J Z, Guan B, et al. Optimization of 1-lysine medium by response surface methodology. Food \& Machinery, 2015; 31(5): 256-260. (in Chinese)

[15] Zhang W, Zhang Q, Ruan X Y, Wang X Z, Kong H N, Lin Y Optimization of enzymatic hydrolysis of wheat straw by using response surface methodology. Biomass Chemical Engineering, 2015; 49(2): 39-46. (in Chinese)

[16] Liu S, Fan B Q. Screening of a straw cellulose-degrading fungi qsh3-3 and study on its characteristics of cellulase production. Plant Nutrition \& Fertilizer Science, 2012; 18(1): 218-226.

[17] Zhang C M. Screening of bacteria decomposing low-temperature cellulose and the application of composite microbial inoculants in straw returning to field. MS dissertation, Nanjing Agriculture University, 2014. (in Chinese)

[18] Chen L. Breeding and fermentation medium optimization of cold-active cellulase strain CNY086(I). Microbiology, 2009; 36(10): 1547-1552. (in Chinese) 